DOI: https://doi.org/10.32839/2304-5809/2021-11-99-13

удК 37.02

Федченко Н.О.

Холминська ЗОШ I-III ст.

\title{
ФОРМУВАННЯ ЗДОРОВ’ЯЗБЕРІГАЮЧИХ КОМПЕТЕНЦІЙ НА УРОКАХ БІОЛОГІЇ
}

Анотація. Автором розглянуто здоров’язберігаючі компетенції на уроках біологіі. Доведено, що у зв'язку 3 цим невипадково одним з напрямків діяльності сучасної школи є збереження здоров'я підростаючого покоління. 3 цією метою використовуються здоров'язберігаючі технології, які передбачають поєднання педагогічних, психологічних і медичних впливів, спрямованих на охорону і забезпечення здоров'я, форомування ціннісного ставлення до нього. Визначено, що екологічний простір також відіграє величезну роль у зміцненні здоров'я студентів: вентиляція, озеленення, освітлення кабінету. Запахи благотворно впливають на здоров'я і настрій, найкращим джерелом яких е рослини. Крім того, вирішуеться освітне завдання: діти, що займаються доглядом за рослинами, привчаються доглядати за ними, за всім живим, отримуючи основи екологічної освіти.

Ключові слова: уроки біології, здоров’язбергаючі компетенції, соціальні цінності, спосіб життя, здоров’я.

Fedchenko Nina

Kholmyn Secondary School

\section{FORMATION OF HEALTH-SAVING COMPETENCIES DURING BIOLOGY CLASSES}

Summary. The author considers healthy competencies in biology lessons. It is proved that in this connection it is not accidental that one of the activities of a modern school is to preserve the health of the younger generation. For this purpose, health technologies are used, which provide a combination of pedagogical, psychological and medical influences aimed at protecting and ensuring health, the formation of values. It is determined that the ecological space also plays a huge role in strengthening the health of students: ventilation, landscaping, office lighting. Smells have a beneficial effect on health and mood, the best source of which are plants. In addition, the educational task is solved: children who take care of plants, learn to care for them, for all living things, receiving the basics of environmental education. The study of subjects of the natural cycle provides students with an effective perception of the holistic scientific and natural picture of the world, understanding the role and place that man plays in nature. At today's stage of development of human society, the issue of environmental literacy is more relevant than ever. The state of the environment is one of the factors in the state of human health. Mankind has severed ties with the outside world, resulting in exacerbation of environmental problems. Food is no longer able to fill the human body with all the nutrients, it has too many harmful components. Weakening of immunity, the birth of sick people - a natural result of the destruction of the environment. The author proves that the introduction of health technologies requires the teacher to avoid overloading students, determining the optimal amount of educational information and ways to provide it, take into account the intellectual and physiological characteristics of students, individual language characteristics of each student, try to plan such activities that reduce fatigue. Health-preserving technologies include: change of activities, alternation of intellectual, emotional, motor activities; group and pair forms of work, which help to increase motor activity, teach the ability to respect the opinions of others, to express their own opinions, the rules of communication; conducting games and game situations, non-standard lessons, integrated lessons.

Keywords: biology lessons, health competencies, social values, lifestyle, healthy.

$\Pi^{2}$ остановка проблеми. У світі $€$ дві основні проблеми: здоров'я нашої планети і здоров'я людей, що живуть на ній. Від вирішення цих проблем залежить як сьогодення, так і майбутне людства. На жаль, медичні працівники констатують значне скорочення числа абсолютно здорових дітей (їх не більше 10-12\%); стрімке зростання числа фрункціональних розладів і хронічних захворювань, які реєструються більш ніж у 50-60\% школярів; різке збільшення частки патології нервової системи, органів чуття, серцево-судинної і травної систем, опорнорухового апарату, нирок і сечовивідних шляхів; збільшення числа школярів 3 множинними діагнозами (20\% старшокласників мають в анамнезі 5 і більше діагнозів).

Існуе кілька груп здоров'язберігаючих технологій, найбільш значущими з яких, за ступенем впливу на здоров'я учнів, $є$ здоров'язберігаючі освітні технології навчання, засновані на вікових особливостях пізнавальної діяльності дітей, навчання на оптимальному рівні складності, варіативності методів і форм навчання, оптимальному поєднанні рухових і статичних навантажень, навчання в малих групах, використання наочності, поєднання різних форм надання інфрормації, створення емоційно сприятливої атмосфрери, фрормування позитивної мотивації до навчання, розвиток знань студентів 3 питань охорони здоров'я.

Аналіз останніх досліджень і публікацій. В працях таких фрілософрів як: Платона, Арістотеля, Гіппократа, Ібн Сена (Авіценна) і багато інших, знаходимо висловів про здоров'я особистості. Вони всі говорять, що здоров'я і життя $\epsilon$ найважливішою цінністю людини. На сьогоднішній час, наше здоров'я повністю залежить від нас. Тому завдання вчителів: прищепити учням навички здорового способу життя та набути відповідних знань і умінь, щоб з гідністю долати життеві труднощі.

Мета статті: вивчення здоров'язберігаючих компетенцій на уроках біології, як вони впливають на розвиток цілісної особистості. Описати, 
як вчителі біології прагнуть у своїй роботі розвинути у молодого покоління любов та жагу до фрізичних вправ.

Виклад основного матеріалу. У нашій країні спостерігається значне погіршення здоров'я дітей, в основному пов'язане зі збільшенням обсягу і ускладненням характеру робочого навантаження, ускладненням характеру взаємин учня і вчителя і міжособистісних відносин в класі, недостатньою руховою активністю, неправильним харчуванням учнів, недотриманням гігіенічних вимог при організації навчального процесу, відсутністю елементарних знань про те, як стати здоровим.

У контексті соціально-економічних змін, що відбуваються в сучасному українському суспільстві, проблема фрормування здорового способу життя особистості займає важливе місце. У вічному пошуку істини людство нарешті усвідомило, що головною соціальною цінністю $є$ людське життя і здоров'я, а рівень цивілізації визначається духовним, інтелектуальним і фізичним розвитком кожної людини.

Чому ми сьогодні обговорюемо тему охорони здоров'я в школі? Тому що здоров'я дітей - одне з головних джерел щастя, радості і повноцінного життя для батьків, вчителів і суспільства в цілому. Школа не може залишатися осторонь від вирішення таких нагальних завдань, як збереження генофонду нації [2, с. 90].

Здоров'я нації в наш час розглядаеться як показник цивілізованості держави, що відображає соціально-економічне становище суспільства. Саме тому, державна політика щодо здорового способу життя формуеться цілеспрямовано і послідовно [5].

Життя і здоров'я людини є вищими соціальними цінностями в нашій державі. Це визначено Конституцією України. На школу як державну установу покладено виконання важливого завдання - виховання здорового покоління.

Кожна школа повинна бути школою зміцнення здоров'я. Життедіяльність такої школи заснована на непідробному інтересі і повазі до дитини; на допомозі в пошуку життевого шляху людини; на формуванні та закріпленні соціального досвіду, а головне - на збереженні психофізичного здоров'я учня [1, с. 4].

Важливою складовою шкільної освіти є фрормування мотиващії до збереження і зміцнення здоров'я. Саме на досягнення цієї мети спрямований предмет «Біологія». Його завдання-фрормування в учнів усвідомленого ставлення до власного життя і здоров'я, оволодіння основами здорового способу життя, життевими навичками безпечної і здорової поведінки, фрормування здоров'язберігаючих компетенцій школярів.

Формування здоров'язберігаючої компетентності, безумовно, є складною проблемою, що вимагає постійної систематичної педагогічної діяльності в цьому напрямку. Тому вчителю необхідно знайти резерви власної активності в збереженні і зміцненні здоров'я учнів.

Доцільно починати роботу в цьому напрямку в початковій школі з вибору здоров'язберігаючих технологій, комплексних цільових програм культури здоров'я і відразу ж приступати до їх реалізації, не ставлячи дитини в ситуацію вибору, щоб здоров'язберігаючий компонент став звичною і невід'ємною частиною освітнього процесу для учнів і батьків [7].

На рубежі середнього рівня необхідно включити механізми особистісного розвитку, а саме самовизначення ставлення учнів до здорового способу життя, продовження реалізації запущених програм, включення питань здоров'язбереження в усі предмети шкільного курсу. В середньому шкільному віці, на етапі розвитку саморегуляції, учням слід запропонувати освоїти кілька різних позакласних занять і фракультативних курсів, комплексних або містять аспекти охорони здоров'я. Таким чином, до старшої школи підлітки вмотивовані і свідомо набувають компетенції, спрямовані на збереження i розвиток власних ресурсів здоров'я і фрормування відповідального ставлення до здоров'я.

Учитель біології може бути «першопрохідцем» в цій галузі освітнього процесу, оскільки питання збереження і зміцнення здоров'я завжди входили в його компетенцію в силу його педагогічної спеціальності. Виховна робота, інтеграція між предметами, підготовка програм з культури здоров'я, організація позакласних заходів в цьому напрямку, екологізація освіти, тобто більшість напрямків здоров'язбереження в школі вчитель біології може і повинен включати в свою освітню діяльність [7].

Одним з найважливіших аспектів є психологічний: комфорт учнів під час уроку. Доброзичлива атмосфрера в класі, спокійна бесіда, увага до кожного висловлювання, тактовне виправлення допущених помилок, відповідний гумор або невелике історичне відступ - це далеко не весь арсенал, яким може володіти вчитель, який прагне розкрити здібності кожної дитини. В обстановці психологічного комфорту і емоційного підйому ефрективність занять помітно зростає, що в кінцевому підсумку призводить до кращого засвоєння знань i, як наслідок, до більш високих результатів [7].

Для ефективного викладання в арсеналі вчителя повинні бути диференційовані завдання, що підвищують ефективність навчання учнів 3 різним рівнем здатності до навчання. Вони сприяють формуванню компетенцій задач комплексного характеру, наприклад, з математичним змістом і практичним застосуванням в житті.

Очевидно, що якщо ви хочете навчити учнів творчості, шукаючим, то вам потрібно навчити їх творчим навичкам. Для цього на уроках створюються творчі завдання. Систематично пошукова i творчий робот організовуються у великих і малих групах, де "проти всіх" і "проти успіху». Це форма організації занять на уроках біології, для того, щоб привести до позитивних результатів в області навчання, оскільки розвиток комунікативних і регулятивних універсальних навчальних виробів, пов'язаних з соціальним здоров'ям учнів.

Екологізація всього курсу біології є актуальною частиною освітнього процесу, оскільки вона пов'язана $з$ аспектами збереження здоров'я, охорони природи та екологічного світогляду. Розгляд певних питань і тем, особливо регіональних, з екологічної точки зору сприяе розвитку екологічної культури та культури здорового способу життя [6, с. 23-24]. 
Говорячи про наповнення змісту уроку питаннями здоров'язбереження, необхідно враховувати основний зміст теми уроку, вікові особливості учнів, регіональний компонент у навчанні.

Формування екологічної культури учнів здійснюеться через інтеграцію предметів шкільного курсу. Важлива активна педагогічна позиція і виховна роль вчителя біології у формуванні екологічної культури учнів за допомогою інтеграції наук і предметів.

Організація і проведення інтегрованих уроків і заходів, які можливі між предметом «Біологія» і всіма предметами, повинні здійснюватися в системі. Тільки тоді, коли учень отримає екологічні знання не тільки на уроках біології, а й з математики, фрізики, формування цілісного екологічного світогляду буде успішним і ефективним. Зміст таких уроків включае в себе отримання знань з основних розділів екології та екології рідного краю (Краєзнавство) [5].

Екологічну освіту необхідно починати вже в початковій школі. Учитель біології у співпращі з методичним об'єднанням вчителів початкових класів, із залученням учнів середньої ланки, може організувати інтегровані уроки, а також заняття пропедевтичного характеру. Спільно 3 вчителями інших предметів вчитель біології складае програми та методичні посібники з екологізації шкільних предметів, а саме рекомендації з викладання того чи іншого предмета, включаючи питання екологічної освіти.

Формування здоров'язберігаючої компетенції має бути комплексним і безперервним, тому в навчальний план шкільного курсу вводяться програми позакласних занять, цілями і завданнями яких $є$ розвиток учнів у всіх напрямках: соціальному, інтелектуальному, спортивно-оздоровчому, загальнокультурному. Заняття проводяться у формі екскурсій, гуртків, секцій, круглих столів на різні теми, пов'язані з формуванням і розвитком здоров'язберігаючої компетентності.

Особливою популярністю у школярів користуються курси, програми яких включають туристичні поїздки і походи, практичне вивчення природних і культурних об'єктів. У довгострокових групових поїздках діти найбільш ефективно формують і розвивають компетенції, особливо здоров'язберігаючі.

Одним з ефективних методів роботи з розвитку здоров'язберігаючої компетентності є організація дослідницької та проектної діяльності учнів. Науково-дослідна діяльність дозволяе одночасно вирішувати питання освіти, розвитку і виховання підростаючого покоління. Залучення учнів в дослідницьку діяльність сприяе розвитку задоволеності собою і своїм результатом, забезпечуе переживання, осмисленість, значимість того, що відбуваеться, є основою для його подальшого самовдосконалення і самореалізації. При проведенні дослідження виховуються якості повноцінної гармонійно розвиненої, соціально та інтелектуально здорової особистості [6, с. 24].

Вчителю біології найчастіше доводиться мати справу з проектами на теми здоров'я, екологічного стану навколишнього середовища, охорони навколишнього середовища, але, як правило, теми завжди носять інтегративний природничонауковий характер. Останнім часом учні все час- тіше пропонують теми досліджень самостійно, іноді найнесподіваніші, що не може не радувати викладача. Обрана тема завжди повинна бути прийнята і підтримана, так як це свідчить про ефрективність освітнього процесу, формуванні пізнавального інтересу і мотивації до розвитку.

Якщо сам учитель володіє якостями дослідника, мандрівника, то прищепити ці якості дітям можна за допомогою спільних екскурсій, поїздок. При цьому формуються і розвиваються всі складові здоров'я: фізичне, психоемоційне, інтелектуальне, особистісне, соціальне, духовне.

Учитель представляе свою активну позицію щодо зміцнення і збереження здоров'я у формі презентацій власного досвіду роботи, особистих досягнень, статей, наукових робіт. Безсумнівно, цей вид діяльності займає багато часу, але він е невід'ємною частиною формування здоров'язберігаючої компетентності, як соціально активна діяльність з пропаганди здорового способу життя.

При вивченні травної системи діти знайомляться зі складом харчових продуктів, їх енергетичною цінністю і потребою людини в енергії, одержуваної з їжі. Необхідно звернути увагу учнів на необхідність своєчасного і збалансованого харчування, провести роботу з підвищення культури харчування, дотримання елементарних гігієнічних вимог. Школярі вчяться складати меню 3 урахуванням вимог до здорового харчування, отримують необхідну інформацію про процеси, що відбуваються з їжею під час її приготування.

Велику увагу слід приділяти суворому нормуванню домашніх завдань для запобігання перевантажень, звертаючи особливу увагу на обсяг і складність матеріалу, призначеного для дому. Основні моменти завдання слід розібрати на уроці, а повторення залишити вдома.

Для вчителя дуже важливо правильно організувати урок, тому що це основна форма педагогічного процесу. Тому раціональна щільність уроку повинна становити не менше $60 \%$ і не більше 75-80\%; зміст уроку мае включати питання, пов'язані зі здоров'ям учнів, що сприяють формуванню у них цінностей здорового способу життя і потреб; кількість видів навчальної діяльності на уроці мае становити 4-7, а їх зміна повинна здійснюватися за 7-10 хвилин; урок має включати в себе заходи, що сприяють розвитку пам'яті, логічного і критичного мислення; під час уроку слід використовувати не менше 2-х педагогічних технологій, що сприяють активізації ініціативи та творчого самовираження учнів; навчання повинно проводитися 3 урахуванням провідних каналів сприйняття інформації учнями (аудіовізуальних, кінестетичних і т. д.); слід контролювати наукове якість досліджуваного матеріалу; необхідно формувати зовнішню і внутрішню мотивацію діяльності учнів, здійснювати індивідуальний підхід до дітей з урахуванням особистих можливостей; на урощі необхідно створювати сприятливий психологічний клімат і обов'язково ситуації успіху та емоційної розрядки, тому що результат будь-якої роботи, особливо розумової, залежить від настрою, від психологічного клімату в недружній атмосфері ,втома приходить швидше; необхідно включити в урок технологічні прийоми й методи, що сприяють самопізнанню, підвищен- 
ня самооцінки учнів; необхідно для підвищення працездатності і придушення втоми включити в урок фрізкультурні хвилини, визначити їх місце, зміст і тривалість (бажано на 20-й і 35-й хвилинах уроку, тривалість - 1 хв, що складається 33 легких вправ по 3-4 повторення кожне), необхідно цілеспрямовано міркувати протягом усього уроку і в його заключній частині [4, с. 2].

Рівень гігієнічної ращіональності уроку багато в чому визначає функціональний стан школярів в процесі навчальної діяльності, здатність тривалий час підтримувати розумову працездатність на високому рівні і запобігати передчасне стомлення. Ми не повинні забувати, що гігієнічні умови також впливають на стан вчителя і його здоров'я. А це, в свою чергу, впливає на стан і здоров'я учнів [6, с. 23].

Турбота про здоров'я дітей невіддільна від турботи вчителя про своє власне здоров'я. Учитель повинен подавати приклад своїм способом життя і своїм здоров'ям, так як його власний приклад, краще будь-яких слів познайомить дітей з правилами здорового способу життя.
Виховна діяльність вчителя і його учнів по формуванню здоров'язберігаючої компетентності, збереженню і зміцненню здоров'я являе собою безперервний, системний, комплексний процес. Тільки завдяки комплексному підходу до навчання і спільної діяльності всіх учасників освітнього процесу можуть бути успішно вирішені завдання формування і зміцнення здоров'я школярів.

Висновки. Показниками наявності екологічної культури і формування здоров'язберігаючої компетентності у дітей можна вважати активну участь в здоров'язберігаючих заходах, виконання проектів і наукових досліджень, участь в тематичних конкурсах і олімпіадах, представлення своеї творчої діяльності на різних рівнях, активне фрізичне виховання і спорт, дотримання правил поведінки на природі. Позитивні відгуки учнів та їх батьків, інших освітніх організацій, а також позитивні оцінки діяльності та нагороди учнів і викладачів свідчать про те, що діяльність вчителя в цьому напрямку є ефрективною та успішною.

\section{Список літератури:}

1. Баран О. Формування дослідницьких компетентностей у процесі екологічного виховання учнів. Біологія. 2018. № 34/36. С. 4-10.

2. Бойчук Ю. Д. Сучасні підходи до розуміння сутності здоров’я людини та суміжних з ним понять. Загальна теорія здоров'я та здоров'язбереження : колективна монографія / за заг. ред. проф. Ю. Д. Бойчука. Харків : Вид. Рожко С. Г., 2017. 488 с.

3. Гончарук О. Л. Формування здоров'язбережувальних компетентностей учнів через запровадження здоров'язбережувальних технологій. Основи здоров'я. 2019. № 6. С. 2-11.

4. Клименко С. Формування здоров'язбережувальної компетентності на уроках. Основи здоров'я. 2019 . № 9. C. 2-7.

5. Основи здоров'я. 5-9 класи. Програма для загальноосвітніх навчальних закладів / Укладачі програми (2012 р.): Т. Є. Бойченко, Т. В. Воронцова, О. Л. Москаленко, С. С. Фіцайло, В. В. Дерев'янко, В. С. Пономаренко, Н. М. Поліщук. Над оновленням програми (2017 рік) працювали: О. І. Шиян, Т. Г. Боса, О. А. Спірке, O. I. Шаповал. URL: https://imzo.gov.ua/osvita/zagalno-serednya-osvita-2/navchalni-prohramy-5-9-klasy-naskriznizmistovi-liniji/osnovy-zdorov-ya-naskrizni-zmistovi-liniji/

6. Семенюк В. Формування здоров'язбережувальної компетентності на уроках біології. Біологія. 2019 . № 9. C. 23-33.

7. Заріцька С. Формування здоров'язберігаючої компетентності та екологічне виховання на уроках природничого циклу. URL: https://rmk-mv.blogspot.com/2018/02/blog-post_36.html

8. Шулик О. А. Формування життевих компетентностей учнів на уроках основ здоров'я через діяльнісний підхід у навчанні. Безпека життедіяльності. 2019. № 1. С. 11-13.

\section{References:}

1. Baran O. (2018) Formuvannya doslidnic'kih kompetentnostej u procesi ekologichnogo vihovannya uchniv [Formation of research competencies in the process of ecological education of students]. Biology, no. 34/36, pp. $4-10$.

2. Boychuk Y.D. (2017) Formuvannya doslidnic'kih kompetentnostej u procesi ekologichnogo vihovannya uchniv [Modern approaches to understanding the essence of human health and related concepts. General theory of health and health conservation]. Kharkiv: Ed. Rozhko S.G.

3. Goncharuk O.L. (2019) Formuvannya zdorov'yazberezhuval'nih kompetentnostej uchniv cherez zaprovadzhennya zdorov'yazberezhuval'nih tekhnologij [Formation of health-preserving competencies of students through the introduction of health-preserving technologies]. Fundamentals of health, no. 6, pp. 2-11.

4. Klimenko S. (2019) Formuvannya zdorov'yazberezhuval'noï kompetentnosti na urokah [Formation of healthpreserving competence in lessons]. Fundamentals of healt, no. 9, pp. 2-7.

5. Compilers of the program T.E. Boychenko, T.V. Vorontsova, O.L. Moskalenko, S.S. Fitsailo, V.V. Derevyanko, V.S. Ponomarenko, N.M. Polishchuk. O.I. Shiyan, T.G. Bosa, O.A. Spirke, O.I. Shapoval (2017) Osnovi zdorov'ya. 5-9 klasi. Programa dlya zagal'noosvitnih navchal'nih zakladiv [Basics of health. Grades 5-9. Program for general educational institutions]. Available at: https://imzo.gov.ua/osvita/zagalno-serednya-osvita-2/navchalni-prohramy5-9-klasy-naskrizni-zmistovi-liniji/osnovy-zdorov-ya-naskrizni-zmistovi-liniji/ (accessed 13 November 2021).

6. Semenyuk V. (2019) Formuvannya zdorov'yazberezhuval'noï kompetentnosti na urokah biologiï [Formation of health-preserving competence in biology lessons]. Biology, no. 9, pp. 23-33.

7. Zaric'ka S. Formuvannya zdorov'yazberigayuchoï kompetentnosti ta ekologichne vihovannya na urokah prirodnichogo ciklu [Formation of health-preserving competence and ecological education in the lessons of the natural cycle] .Available at: https://rmk-mv.blogspot.com/2018/02/blog-post_36.html (accessed 13 November 2021).

8. Shulyk O.A. (2019) Formuvannya zhittevih kompetentnostej uchniv na urokah osnov zdorov'ya cherez diyal'nisnij pidhid u navchanni [Formation of life competencies of students in lessons of basics of health through activity approach in teaching]. Safety of life, no. 1, pp. 11-13. 